\title{
Особенности генерации волоконных лазеров с распределенной обратной связью с коротким резонатором
}

\author{
$\underline{\text { А.М. Смирнов }}^{1, *}$, А.П. Базакуца ${ }^{1}$, О.В. Бутов ${ }^{1}$ \\ ИРЭ им. В.А. Котельникова РАН \\ *E-mail: alsmir1988@mail.ru
}

DOI:10.31868/RFL2018.61-62

В работе представлено исследование особенностей генерации волоконного лазера с распределенной обратной связью (РОС-лазера) на основе высоколегированного эрбием волоконного световода. Заготовка для световода была синтезирована с помощью плазмохимической технологии SPCVD, благодаря чему удалось получить высокую концентрацию оксида эрбия в стекле (на уровне 0,3 мол.\% $\mathrm{Er}_{2} \mathrm{O}_{3}$ ) с минимальным уровнем его кластеризации. Дополнительно сердцевина световода была солегирована алюминием. Спектр поглощения световода приведен на Рис.1. Уровень поглощения на характерных длинах волн 980 нм и 1530 нм составил 80 дБ/м и 180 дБ/м, соовтетственно. Важено отметить отсутствие ионов иттербия в сетке стекла сердцевины, которые дополнительно легируют стекло для повышения эффективности накачки эрбиевых лазеров [1]. Высокая концентрация редкоземельных элементов наряду с малым уровнем кластеризации важна для создания волоконных лазеров с коротким резонатором, в том числе, РОС-лазеров [2,3]. В данной работе были исследованы режимы работы РОС-лазера с резонатором длиной 50 мм. Накачка лазера осуществлялась непосредственно в сердцевину волокна, легированную эрбием, на длине волны 976 нм (Рис.2), лазер при этом работал в импульсном режиме. Для повышения эффективности накачки лазера был использован дополнительный рефлектор на выходе резонатора в виде брэгговской решетки, которая отражала непоглощенную энергию накачки обратно в резонатор.

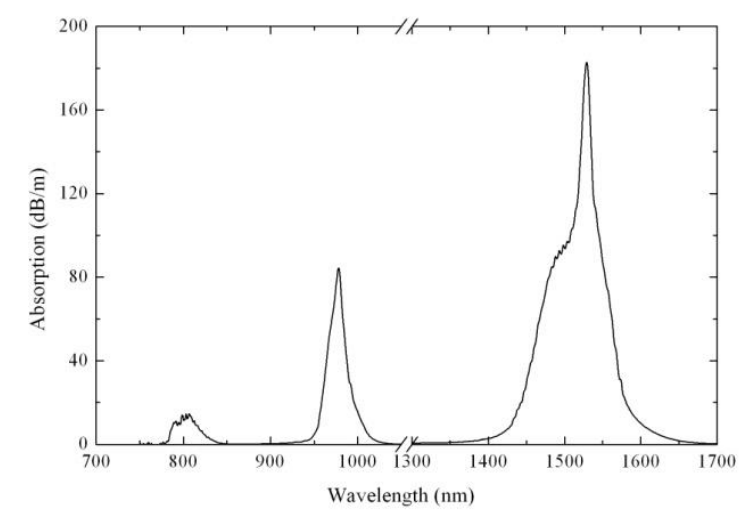

Рис.1. Спектр поглощения активного волокна.

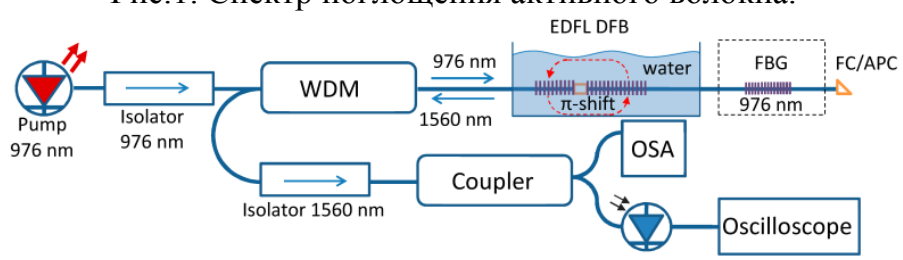

Рис.2. Схема экспериментальной установки для исследования режима генерации РОС-лазера. 
Полученная в эксперименте импульсная генерация РОС-лазера при разных значениях мощности накачки показана на Рис. За. Частота следования импульсов, a также их длительность зависят от интенсивности накачки и наличия дополнительного рефлектора в схеме лазера. Максимальная частота 700 кГц и пиковая мощность $0,7 \mathrm{~W}$ (интенсивность $1,4 \mathrm{MW} / \mathrm{cm}^{2}$ ) наблюдались при максимальной мощности накачки 620 мВт при использовании дополнительной брэгговской решетки, отражающей непоглощенную энергию накачки обратно в резонатор. При этом длительность импульса сокращалась до 71 нс. Зависимость частоты следования импульсов и их длительности от мощности накачки приведены на Рис. 3б.

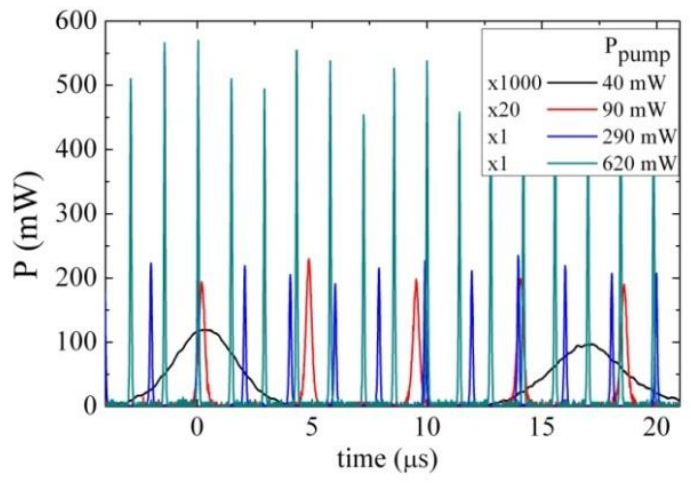

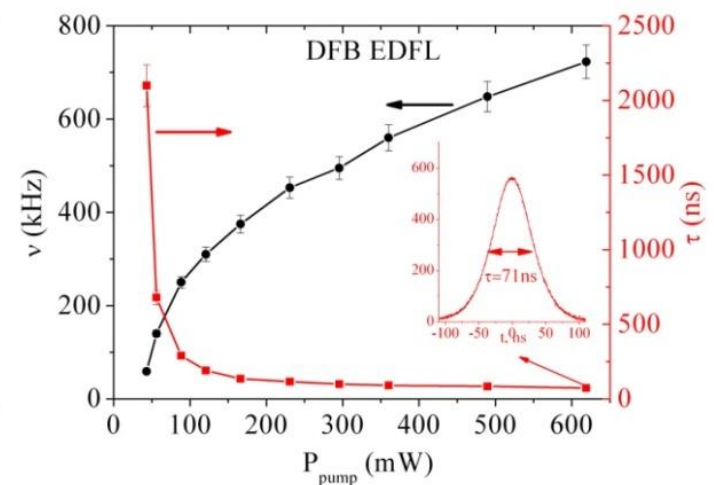

б

Рис.3. а) Режимы генерации РОС-лазера в зависимости от мощности накачки. б) Зависимость частоты следования импульсов и длительности импульсов от мощности накачки.

Импульсный режим работы эрбиевых волоконных лазеров хорошо известен [4,5]. Ранее было показано [4], что возникновение импульсного режима обусловлено кластеризацией - существованием близкорасположенных пар ионов $\mathrm{Er}^{3+}$ в сильнолегированной усиливающей среде. В этих парах существует процесс ап-конверсии, сводящийся к появлению сильного поглощения, возникающего при возбуждении обоих ионов в паре. В результате возникает поглощение, зависящее от населенностей уровней. В работах $[4,6]$ показано, что в результате возникает пассивная модуляция добротности [7] благодаря чему развивается режим импульсной генерации.

Работа выполнена при поддержке РФФИ (проект 17-07-01388).

\section{Литература}

[1] J.T. Kringlebow, J.-L. Archambault, et al., Opt. Lett. 19(24), 2101-2103 (1994).

[2] Oleg V. Butov, Andrey A. Rybaltovsky et al., JOSA B, 34(3), A43-A48 (2017)

[3] O.V. Butov, A.A. Rybaltovsky et al., Spring PIERS, St Petersburg, Russia, 1594 - 1597, (2017)

[4] F. Sanchez, P.L. Boudec et. al., Phys. Rev. A., 48(3), 2220-2229 (1993).

[5] M I Skvortsov, A A Wolf et. al., Laser Phys. Lett. 15035103 (2018)

[6] F. Sanchez and G. Stephan, Phys. Rev. E 53(3), 2110-2122 (1996)

[7] Svelto O., Principles of lasers, Springer, pp.648 (2009) 